\title{
Towards early dental caries detection with OCT and polarized Raman spectroscopy
}

\author{
Lin-P'ing Choo-Smith ${ }^{1,2^{*}}$, Mark Hewko ${ }^{1}$, Michael Sowa ${ }^{1}$ \\ From 2nd Scientific Meeting of the Head and Neck Optical Diagnostics Society \\ San Francisco, CA, USA. 23-24 January 2010
}

In recent years, we have been developing optical coherence tomography (OCT) and polarized Raman spectroscopy (PRS) for the detection of early noncavitated dental caries. OCT provides high resolution morphological depth imaging of incipient caries. With OCT, early lesions can be readily identified as regions of high light backscattering with depth into the enamel as compared to health sound enamel. From the OCT images, the lesion depth can be approximated to provide clinically useful information to guide treatment decisions. In addition, we have derived a parameter known as the optical attenuation coefficient in order to distinguish sound from carious enamel non-subjectively. OCT is being combined with PRS since regions of high light backscattering not related to caries development can lead to false-positive results. PRS provides biochemical specificity along with molecular structural/orientational information. With PRS, the Raman depolarization ratio calculated from the main phosphate vibration at $\sim 959 \mathrm{~cm}^{-1}$ from parallel- and cross-polarized Raman spectra allows discrimination between sound and early developing caries. Early studies on lab bench instrumentation are now being translated into fibre-optic based devices for intra-oral use in patient volunteers for clinical validation. In combination, OCT and PRS have potential for detecting and monitoring early lesions with high sensitivity and high specificity.

\section{Author details}

${ }^{1}$ Institute for Biodiagnostics, National Research Council Canada, Winnipeg, MB, Canada. ${ }^{2}$ Dept. Restorative Dentistry, Faculty of Dentistry, University of Manitoba, Winnipeg, MB, Canada.

\footnotetext{
Institute for Biodiagnostics, National Research Council Canada, Winnipeg, MB, Canada
}

Full list of author information is available at the end of the article
Published: 29 October 2010

doi:10.1186/1758-3284-2-S1-043

Cite this article as: Choo-Smith et al.: Towards early dental caries detection with OCT and polarized Raman spectroscopy. Head \& Neck Oncology 2010 2(Suppl 1):O43.
Submit your next manuscript to BioMed Central and take full advantage of:

- Convenient online submission

- Thorough peer review

- No space constraints or color figure charges

- Immediate publication on acceptance

- Inclusion in PubMed, CAS, Scopus and Google Scholar

- Research which is freely available for redistribution

Submit your manuscript at www.biomedcentral.com/submit
C Biomed Central 